
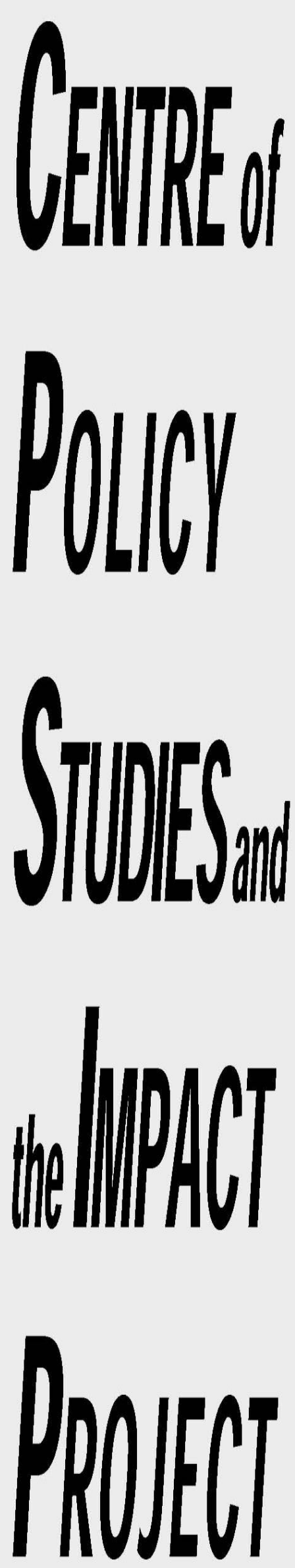

Eleventh Floor, Menzies Building Monash University, Wellington Road CLAYTON Vic 3800 AUSTRALIA

Telephone:

(03) 9905 2398, (03) 99055112

Fax:

(03) 99052426

e-mail:

Internet home page: from overseas: 61399052398 or 61399055112

61399052426 impact@buseco.monash.edu.au http//www.monash.edu.au/policy/

\title{
Reform of Australian Urban Transport: A CGE-Microsimulation Analysis of the Effects on Income Distribution
}

\author{
by \\ GEORGE VERIKIOS \\ Centre of Policy Studies \\ Monash University \\ And \\ XIAO-GUANG ZHANG \\ Productivity Commission
}

General Paper No. G-239 December 2013

The Centre of Policy Studies (COPS) is a research centre at Monash University devoted to economy-wide modelling of economic policy issues. 



\title{
REFORM OF AUSTRALIAN URBAN TRANSPORT: A CGE- \\ MICROSIMULATION ANALYSIS OF THE EFFECTS ON INCOME \\ DISTRIBUTION
}

\author{
George Verikios \\ Centre of Policy Studies, Monash University \\ Xiao-guang Zhang \\ Productivity Commission
}

\begin{abstract}
$\underline{\text { Abstract }}$
Australian urban transport industries experienced substantial reform during the 1990s leading to significant structural change. Urban transport is typically an important expenditure item for households and structural change in these services may affect households differently depending on their position in the distribution of income and expenditure. We estimate the effects on household income groups of this structural change by applying a computable general equilibrium model incorporating microsimulation behaviour with top-down and bottom-up links. We compare estimates based on a pure microsimulation approach, a top-down approach and a hybrid top-down/bottom-up approach. We estimate small reductions in real income and small reductions in inequality; this pattern is largely replicated across regions. Our results are insensitive to the inclusion of bottom-up links; in contrast, applying a pure microsimulation approach gives accurate results at the aggregate level but underestimates the variation in effects across deciles and regions.
\end{abstract}

JEL codes: $\quad$ C68, C69, D31, L92.

Keywords: $\quad$ computable general equilibrium, income distribution, microeconomic reform, microsimulation, urban transport.

\section{Acknowledgements}

The views expressed here are the authors' and do not necessarily reflect those of the Productivity Commission or Monash University. Thanks are due to Ken Clements for helpful comments on this work. 


\section{Table of contents}

1. Introduction 1

2. Changes in urban transport during the 1990s 4

2.1 Urban transport and microeconomic reform 4

2.2 Structural change in urban transport 4

3. Method: a CGE top-down/bottom-up microsimulation approach 6

$\begin{array}{lll}3.1 & \text { Overview } & 6\end{array}$

$\begin{array}{lll}3.2 & \text { The macro dimension } & 7\end{array}$

$\begin{array}{lll}3.2 .1 & \text { A linear equation system } & 8\end{array}$

$\begin{array}{lll}\text { 3.2.2 Behavioural equations } & 8\end{array}$

3.2.3 Model closure $\quad 12$

3.3 The micro dimension 13

$\begin{array}{lll}3.3 .1 & \text { Theory } & 13\end{array}$

$\begin{array}{lll}3.3 .2 & \text { Data } & 16\end{array}$

4. Results 17

$\begin{array}{lll}4.1 & \text { Direct effects: micro simulation } & 17\end{array}$

$\begin{array}{lll}\text { 4.2 Direct and indirect effects: top-down general equilibrium } & 19\end{array}$

4.3 Direct and indirect effects: top-down/bottom-up general equilibrium 24

5. Discussion and concluding remarks 25

$\begin{array}{ll}\text { References } & 28\end{array}$ 


\section{Tables}

1 Structural changes in urban transport: 1989/90-1999/00 (percentage change) 5

2 Mapping between MMRF income sources and household income sources 15

$3 \quad$ Selected expenditure and income shares, national 17

4 Effects on household real income and its components (percentage change) 18

5 Effects on household real income and inequality (percentage change) 19

6 Macroeconomic effects of changes in urban transport: 1989/90-1999/00 $\begin{array}{ll}\text { (percentage change) } & 20\end{array}$

7 Urban transport industry effects due to changes in unit-output employment and relative output prices: 1989/90-1999/00 (percentage change)

8 Microeconomic effects of changes in the urban transport industries: 1989/90-1999/00 (percentage change) 22

9 Effects on household real income and inequality (percentage change) 23

10 Decomposition of national household income effects 24

11 Effects on household real income and inequality (percentage change) 25 


\section{Introduction}

Urban travel is an important component of daily life for households in most high-income countries, but particularly so for Australia where $85 \%$ of the population lives in urban areas. Of the three main modes of urban transport in Australia (road, rail and water) road and rail are the most important. Before the 1990s, most urban transport services in Australia were heavily subsidised by governments, and governments commonly either provided public transport directly or regulated the fares of private service providers (IC, 1994; PC, 2002). Around this time, Australian governments began an extensive process of microeconomic reform of Australian infrastructure industries; this included utilities (e.g., gas, water and electricity supply) as well as urban transport. The reforms were part of the process motivated by the Hilmer Report (Commonwealth of Australia, 1993). The main objectives of these reforms were to increase competition and performance in these industries.

Infrastructure industries are generally major service providers, so reform of these industries can potentially have significant impacts on households, businesses and on other industries. For households, changes in infrastructure prices will directly affect household incomes via cost-ofliving changes. But changes in infrastructure prices can also indirectly affect the cost structure and competitiveness of downstream industries. In turn, this will affect factor incomes to some extent. Changes in factor incomes will affect household incomes; unless such changes affect all households evenly, the distribution of income will also change. Our focus is on quantifying the direct and indirect effects of structural change in urban transport and income distribution. As urban transport services are directly purchased by households and are usually a significant share of household expenditure, a priori, the link between the urban transport industries and income distribution seem direct and strong. In contrast, the indirect links between urban transport industries and other industries seem weak because urban transport is not an important production input for most industries. An alternative indirect link is through the effects on factor market prices via movement of labour and capital across industries, but it is not clear how strong the factor market links are or whether they are positive or negative for households; some scholars contend that the factor market links are unequivocally negative for households, e.g., Quiggin (1997).

To quantify the direct and indirect links between structural change in urban transport and income distribution, we apply an economywide framework with a high degree of sectoral detail and intersectoral linkages: i.e., computable general equilibrium (CGE). CGE analysis of 
reforming infrastructure industries is not common: examples include Argentina's utilities sectors (Benitez et al., 2003); Bolivia's gas sector (Andersen and Faris, 2002); Morocco's rural areas (Löfgren et al., 1997); and Australia's road and rail freight industries (PC, 2006). Analysing the distributional effects of such reforms within a CGE framework is even less common: Boccanfuso et al. examine the impact of electricity industry reform on income distribution in two low-income countries, Senegal (2009a) and Mali (2009b); PC (1996) analyse the effects of electricity and telecommunications reforms on income distribution in Australia; and Verikios and Zhang (2008) analyse the effects of a range of infrastructure reforms on income distribution in Australia.

Our analysis proceeds by incorporating household expenditure and income data within a multi-region CGE model of Australia. Within this framework, we simulate the changes in labour productivity and relative prices of urban transport services during the 1990s to generate regionspecific changes in commodity prices, factor returns and usage. The region-specific changes are linked in a top-down manner to expenditure prices, employment and factor returns at the household level. In contrast, labour supply and commodity demand is determined at the household level and is linked to the CGE model in a bottom-up manner. In the microsimulation literature, this approach is typically referred to as macro-micro (Hertel and Reimer, 2005). Within this class of analysis, it is most accurately sub-classed as a variant of the CGE microsimulation sequential approach (e.g., Chen and Ravallion, 2004), also known as CGE micro-accounting (Boccanfuso et al., 2009a). In CGE micro-accounting, the representation of households is purely an accounting framework with no behavioural responses. Our approach follows that developed by Bourguignon and Savard (2008) by going beyond a pure accounting framework and incorporating micro-feedback effects from labour supply and commodity demand determined at the household level. Incorporating a micro-feedback effect from labour supply and commodity demand determined at the household level addresses one of the main criticisms directed at the macro-micro approach (Bourguignon and Spadaro, 2006; Hertel and Reimer, 2005); it also represents an advance on the few studies that analyse the distributional effects of reforming infrastructure industries within a CGE framework (e.g., Boccanfuso et al., 2009a, b; PC, 1996; Verikios and Zhang, 2008). 


\section{Changes in urban transport during the $1990 \mathrm{~s}^{1}$}

At the beginning of the 1990s, Australian governments began an extensive process of microeconomic reform of Australian infrastructure industries. The objectives of the reforms were to increase competition and performance in infrastructure industries. Prior to the commencement of the reform process, almost all infrastructure industries were dominated by government trading enterprises (GTE) providing services with monopoly rights; this was a feature of industry policy in Australia for most of the $20^{\text {th }}$ century. Thus the reform process has been largely concerned with improving the performance of GTE.

\subsection{Urban transport and microeconomic reform}

Urban transport in Australia comprises passenger travel by railroad (trains), road (tramways, buses and taxi) and water (ferries) in urban areas. In 1997 in the major Australian metropolitan cities, urban passenger services accounted for between 3\% and 30\% of employment in the road and water transport industries, and urban rail services accounted for between $10 \%$ and $40 \%$ of employment in rail transport (SCRGSP, 1998). Before the 1990s, most urban transport services were heavily subsidised by governments, and governments commonly either provided public transport directly or regulated the fares of private service providers. Beginning in 1990, urban transport industries were subjected to many reforms. Principally, these comprised changes to:

- governance arrangements, including commercialisation, corporatisation and, in some cases, privatisation of government-owned service providers;

- market structure, by introducing contestability through competitive tendering for some urban transport services and the partial deregulation of the taxi industry; and

- pricing structures, including reductions in (or the elimination of) government subsidies by aligning prices more closely with the costs of delivering services to different customer groups.

\subsection{Structural change in urban transport}

As a reflection of the effects of the reform process, the economic structure of the urban transport industries at the end of the 1990s was different from that at the beginning of the reform

\footnotetext{
1 Sections 2.1-2.2 draw on PC (2002) and Williams et al. (2005).
} 
process in the early 1990s. The structural changes are reflected in information available on employment, output and prices for these industries. Using these variables, first we calculate the change in employment per unit of output over the 1990s, i.e., gross employment (in persons) divided by the quantity of output. This measures the labour intensity of the industry; its inverse is also a measure of labour productivity. Output is defined as annual boardings. Our second measure of structural change is the relative output price: the output price divided by the consumer price index (CPI), indicating movements in relative price of urban transport services.

Table 1 reports the changes in employment per unit of output and relative prices in urban transport over the 1990s. We see that unit-output employment decreased for road transport in most regions: the maximum decrease being 3.9\% in Victoria (VIC). Unit-output employment increased slightly in Tasmania (TAS) by $0.3 \%$ and by $3.7 \%$ in the Australian Capital Territory (ACT). Much larger changes in unit-output employment occurred in rail transport: $-20 \%$ in VIC, $-16 \%$ in New South Wales (NSW), and around $-9 \%$ in South Australia (NSW) and Western Australia (WA). The large improvements in labour productivity for rail transport indicated in Table 1 over this period have also been noted by Williams et al. (2005). Unit-output employment for water transport only changed marginally over this period.

Table 1. Structural changes in urban transport: 1989/90-1999/00 (percentage change)

\begin{tabular}{|c|c|c|c|c|c|c|c|c|}
\hline Variable & NSW & VIC & QLD & SA & WA & TAS & NT & $\mathrm{ACT}$ \\
\hline & \multicolumn{8}{|c|}{ Road transport } \\
\hline Employment per unit of output & -1.4 & -3.9 & -0.5 & -2.5 & -2.1 & 0.3 & na & 3.7 \\
\hline \multirow[t]{2}{*}{ Relative price } & 14.6 & 16.9 & 79.5 & 21.6 & 47.1 & 22.2 & 25.5 & 45.6 \\
\hline & \multicolumn{8}{|c|}{ Rail transport } \\
\hline Employment per unit of output & -16.1 & -20.0 & -0.1 & -9.0 & -8.4 & na & na & na \\
\hline \multirow[t]{2}{*}{ Relative price } & 23.2 & 10.8 & 11.2 & 21.6 & 47.1 & na & na & na \\
\hline & \multicolumn{8}{|c|}{ Water transport } \\
\hline Employment per unit of output & 1.0 & na & -2.2 & na & 0.2 & na & na & na \\
\hline Relative price & 14.5 & na & 79.5 & na & 47.1 & na & na & na \\
\hline
\end{tabular}

Source: SCNPMGTE (1995, 1996, 1998); PC (2002); Metro Tasmania (2001). See Chapter 4 of Verikios and Zhang (2005) for further details.

Relative prices increased for all forms of urban transport and significantly so in some regions: road and rail transport in Queensland (QLD) increased by around 80\%; all forms of urban transport in WA increased by around 47\%. The smallest price increase was observed for rail transport in VIC (11\%). The general pattern of relative price increases reflect price reforms whereby government subsidies for urban transport were reduced or eliminated and prices were set to more closely reflect the costs of delivering services to different customer groups. 
We apply the changes shown in Table 1 to the CGE model described in the next section. Unit-output employment is typically an endogenous variable in a CGE model. We accommodate applying exogenous changes in unit-output employment by setting labour-augmenting technical change as endogenous. The relative price of any commodity is also typically an endogenous variable in a CGE model. To apply a relative price change in our model we set it as exogenous and set a consumption tax on urban transport as endogenous. Thus, a change in the relative price is assumed to raise tax revenue, which is then used to reduce the large operational deficits incurred by urban transport industries at the beginning of the reform process.

\section{Method: a CGE top-down/bottom-up microsimulation approach}

\subsection{Overview}

Orcutt (1967) was the first to describe a process for linking models that operate at different levels of aggregation, envisioning multiple models being linked through “...adaptors and key variables used as intermediaries..." (p. 120). The approach involved models that describe part of the economy being linked as modules that together would describe the overall system. There is a variety of approaches to linking micro and macro models that are variations on top-down and bottom-up linking methods. The most comprehensive, data intensive and computationally demanding approach is to build a model that inherently includes both a micro and macro dimension (Davies, 2004). Such a model is conceptually attractive but most models in the literature take less demanding approaches due to the practical difficulties of including both dimensions within one model. ${ }^{2}$

In distributional analysis, variations on top-down and bottom-up linking methods are generally referred to as the macro-micro approach. One macro-micro approach that is an example of the top-down method is the CGE micro-accounting approach: here, the micro (household) model is adjusted to match an exogenous macro (CGE) aggregate (e.g., Chen and Ravallion, 2004). Another macro-micro approach is where micro behaviour observed at the household level, such as consumption or labour supply, is integrated into the CGE model (e.g., Bourguignon and Savard, 2008): Savard (2010) refers to this approach as CGE top-down/bottomup microsimulation. Our approach follows that of Bourguignon and Savard (2008) and Savard

2 Cockburn et al. (2008) and Cogneau and Robilliard (2000) are recent examples of CGE models with fully integrated individual households. 
(2010), ${ }^{3}$ as we link a detailed multi-region CGE model with detailed regional household accounts on income and expenditure and incorporate micro-feedback effects from labour supply and commodity demand determined at the household level. The absence of micro-feedback effects in the macro-micro approach has been criticised by Bourguignon and Spadaro (2006) and Hertel and Reimer (2005).

\subsection{The macro dimension}

At the macro level, we apply a comparative-static multi-region CGE model of Australia the Monash Multi-Region Forecasting (MMRF) model (Naqvi and Peter, 1996) - and within it we incorporate individual household income and expenditure accounts. The MMRF model represents the supply and demand side of commodity and factor markets in the eight Australian regions (states and territories). Each region contains five representative agents - producers, physical capital investors, households, governments and foreigners. There are 54 producers in each region, each producing one commodity. Commodities are traded between regions and are also exported internationally. There is a single representative household in each region that owns all factors of production and thus receives all factor income (net of taxes): households can either spend or save their income. Saving contributes to the financing of domestic investment. There are nine government sectors (eight regional and one national). Foreigners supply imports to each region at fixed c.i.f. prices, and demand commodities (exports) from each region at variable f.o.b. prices.

MMRF represents each region in bottom-up form, giving region-specific commodity prices, factor returns and factor usage. Employing a bottom-up regional model allows us to capture region-specific economic changes, and thus we can derive region-specific changes in commodity and factor prices, and region-specific changes in resource allocation across industries. Allowing for region-specific changes in analysing structural change in Australian urban transport industries is important as the reform process did not proceed at an even pace and was not of a similar nature across the Australian regions: this is a function of the reform process being largely the responsibility of regional governments rather than the national government.

\footnotetext{
3 The only substantial difference between our approach Bourguignon and Savard (2008) and Savard (2010) is that we do not recursively adjust the micro (household) and macro (CGE) model results for consistency, but instead allow the micro-feedback mechanisms to directly drive aggregated variables in the CGE model. Recursive adjustment is usually done to 'guarantee' convergence (Savard, 2010, p. 8) but we find no issues with convergence here.
} 


\subsubsection{A linear equation system}

MMRF is represented by equations specifying behavioural and definitional relationships. There are $m$ such relationships involving a total of $p$ variables and these can be compactly written in matrix form as

$$
A \boldsymbol{v}=\mathbf{0}
$$

where $A$ is an $m \times p$ matrix of coefficients, $v$ is a $p \times 1$ vector of percentage changes in model variables and $\mathbf{0}$ is the $m \times 1$ null vector. Of the $p$ variables, $e$ are exogenous (e.g., input-output coefficients). The $e$ variables can be used to shock the model to simulate changes in the $(p-e)$ endogenous variables. Many of the functions underlying (1) are highly nonlinear. Writing the equation system like (1) allows us to avoid finding the explicit forms for the nonlinear functions and we can therefore write percentage changes in the $(p-e)$ variables as linear functions of the percentage changes in the $e$ variables: this improves computational efficiency. Computing solutions to an economic model using (1) and assuming the coefficients of the $A$ matrices are constant is the method pioneered by Johansen (1960). Although (1) is linear, accurate solutions are computed by allowing the coefficients of the $A$ matrices to be nonconstant through a simulation. This is accomplished by using a multistep solution procedure. ${ }^{4}$ Below we present the important behavioural equations for producers in the model.

\subsubsection{Behavioural equations}

Representative firms are assumed to treat the three factors of production (agricultural land, labour and physical capital) as variable and take factor prices as given in minimising costs. Demands for primary factors are modelled using nested production functions consisting of three levels. At the top level, the $j(=1, \ldots, 54)$ firms in the $r(=1, . ., 8)$ regions decide on the (percentage change in) demand for the primary factor composite (i.e., an aggregate of land, labour and capital) $q_{j r}^{F}$ using Leontief production technology:

$$
q_{j r}^{F}=q_{j r}+a_{j r}^{A}
$$

where $q_{j r}$ is (the percentage change in) the $(j, r)$-th industry's activity level, and $a_{j r}^{A}$ is technical change augmenting the use of all production inputs. By applying Leontief production

\footnotetext{
4 The model is implemented and solved using the multistep algorithms available in the GEMPACK economic modelling software (Harrison and Pearson, 1996).
} 
technology, we are assuming that firms' use of the primary factor composite is a fixed share of output, reflecting the idea that the value added share of output is invariant to changes in relative prices and reflects characteristics intrinsic to the production of each good.

At the second level, firms decide on their demand for the $i(=3)$ factors of production, $q_{i j r}^{F}$. All industries face CES (constant elasticities of substitution) production functions:

$$
q_{i j r}^{F}=q_{j r}^{F}+a_{i j r}^{F}-\sigma\left(p_{i j r}^{F}+a_{i j r}^{F}-p_{j r}^{F}\right)
$$

where $\sigma(=0.5)$ is the elasticity of factor substitution, $a_{i j r}^{F}$ is factor $i$-augmenting technical change, and $p_{i j r}^{F}$ is the price of the $i$-th primary factor. $p_{j r}^{F}$ is the price of primary factor composite, i.e., $\sum_{i=1}^{3} S_{i j r}^{F} * p_{i j r}^{F}$ where $S_{i j r}^{F}$ represents factor shares in valued added. For $i=$ Capital, (3) represents stocks of capital used by each industry made up of past investment net of depreciation. Equation (3) consists of a scale term $\left(q_{j r}^{F}+a_{i j r}^{F}\right)$ and a substitution term $\left(p_{i j r}^{F}+a_{i j r}^{F}-p_{j r}^{F}\right)$. Thus, with no change in relative prices, changes in output will lead to changes in factor demands. With output fixed, changes in relative prices will lead to changes in factor demands; this effect will be larger the greater the value of $\sigma$. Any change in $a_{i j r}^{F}$ will affect both the scale and substitution term in (3). All of these effects reflect standard optimising behaviour by the firm. The choice of $\sigma(=0.5)$ is taken from the MMRF model: this is true for all our parameter choices unless otherwise specified. These parameter choices have been extensively applied in applications of the MONASH, MMRF and TERM models. ${ }^{5}$

At level 3, firms decide on their use of the $m(=8)$ labour types (occupations) $q_{m j r}^{L}$ using CES production technology:

$$
q_{m j r}^{L}=q_{i j r}^{F}-\tau\left(p_{m j r}^{L}-p_{j r}^{L}\right), i=\text { labour }
$$

where $\tau(=0.35)$ is the CES between any pair of labour types, and $p_{m j r}^{L}$ is the unit cost to the firm of the $m$-th labour type inclusive of payroll tax. $\quad p_{j r}^{L}$ is the average cost of labour to the firm, i.e., $\sum_{m=1}^{8} S_{m j r}^{L} * p_{m j r}^{L}$, where $S_{m j r}^{L}$ represents occupational shares in the total wage bill. Like factor

\footnotetext{
5 See, for example, Adams et al. (2000), Dixon and Rimmer (2002), Dixon et al. (2011), Horridge et al. (2005) and Wittwer et al. (2005).
} 
demands in (3), equation (4) consists of scale and substitution terms reflecting optimising behaviour.

The labour income data in the household accounts we employ specify labour income by occupation. To exploit the richness of this data, we modify MMRF to allow for an occupationspecific price of labour in each region. To implement occupation-specific wage rates, we add a supply function for the $(m, r)$-th labour type supplied by household $c$ in region $r, l_{m r}^{c}$,

$$
l_{m r}^{c}=\beta^{c} * v_{m r}^{c},
$$

whereby

$$
v_{m r}^{c}=w_{m r}-p_{r}^{c}
$$

where $w_{m r}$ is the average (over all industries) post-tax wage rate received by the $(m, r)$-th labour type, and $p_{r}^{c}$ is the household-specific consumer price index (HCPI) in region $r$ (see Section 3.3.1). So the household supply of each labour type is a positive function of the real wage, $v_{m r}^{c}$, and $\beta^{c}$, the household labour supply elasticity. $\beta^{c}$ is set at 0.15 reflecting econometric evidence on labour supply in Australia (Kalb, 1997).

Given that the changes we are modelling vary greatly by region, the treatment of regional wage adjustment is important to whether a regional change is reflected mainly in regional employment and unemployment or nationwide employment and unemployment. Studies of the Australian labour market show that regional unemployment rates exhibit a high degree of persistence (Kennedy and Borland, 2000). For example, regional unemployment rates take more than 10 to 15 years to return to steady state levels after a negative shock to employment growth (p. 795). To reflect these characteristics, we represent the initial labour market equilibrium as including unemployment in each region. Any new (post-shock) labour market equilibrium will also include unemployment. So changes in labour market equilibrium are determined by imposing a relation between the pre-income-tax real wage rate $r w_{m r}$ and employment $q_{m r}^{L}$ of the form,

$$
r w_{m r}=\gamma^{*} q_{m r}^{L}
$$

whereby

$$
r w_{m r}=w_{m r}-p_{r} .
$$


Equation (8) defines $r w_{m r}$ as the pre-income-tax wage rate deflated by the regional consumer price index. $\gamma$ represents the employment elasticity of the real wage (i.e., the responsiveness of the real wage to changes in employment), and $q_{m r}^{L}=\sum_{j=1}^{54} S_{m j r}^{L} * q_{m j r}^{L}$ (i.e., employment of occupation $m$ across all industries). In any perturbation of the model, $\gamma$ determines the degree to which increases (decreases) in the demand for the $(m, r)$-th labour type will be reflected as higher (lower) employment or a higher (lower) real wage. Put another way, $\gamma$ determines how much unemployment will fall (rise) when the demand for labour rises (falls). Such regionspecific effects on labour demand are likely to be important for how income distribution changes across regions.

We parameterise $\gamma$ by making it depend on whether the real wage is rising or falling. For $r w_{m r} \geq 0, \gamma$ is set at 2 based on casual empiricism of the Australian labour market whereby the real wage rate grows faster than employment. For $r w_{m r}<0, \gamma$ equals 0.5 making real wage rates stickier downwards than upwards, which is also consistent with features of the Australian labour market whereby there is effectively a minimum wage for jobs in most industries (i.e., the award system). Equations (5) and (7) together determine the endogenous unemployment rate for the $(m, r)$-th labour type.

Firms are also assumed to be able to vary the $k(=1, \ldots, 54)$ intermediate inputs they use in production, the prices of which they also take as given in minimising costs. In combining intermediate inputs, all firms are assumed to use nested production functions. At level 1, all firms decide on their use of the intermediate input composite $q_{j r}^{I}$ using Leontief production technology;

$$
q_{k j r}^{I}=q_{j r}+a_{j r}^{A} .
$$

Equation (9) determines firms' use of the intermediate input composite as a fixed share of output, reflecting the idea that the intermediate input share of output is invariant to changes in relative prices and reflects characteristics intrinsic to the production of each good.

At level 2, firms decide on their use of the $k$ intermediate input composites from domestic regions and foreign sources using CES production technology. The CES at this level range between 1 and 2 for most goods; the exceptions are low-value manufactured goods (e.g., textiles, 
clothing and footwear) that are set at 3 or more. As before, optimising behaviour at this level reflects a scale and substitution effects.

At level 3, firms decide on their use of individual intermediate inputs from the $s(=8)$ domestic sources also using CES production technology. The values for the CES at this level range from 2.5 for high-value manufactured goods (e.g., scientific equipment), 8 for primary goods (agriculture), and 10 or more for low-value manufactured goods. These values are an order of magnitude larger than those at level 2, reflecting the greater ease of substituting similar goods from domestic sources as opposed to substituting similar goods from domestic and imported sources.

All firms are assumed to operate in perfectly competitive markets and so we impose a zeropure-profits condition that is expressed as equating revenues with costs; this condition determines

the each industry's activity level $\left(q_{j r}\right)$. Output prices are then determined by a market-clearing condition for each commodity.

\subsubsection{Model closure}

The model contains $m$ equations and $p$ variables where $m<p$, so to close the model $e(=p-$ $m$ ) variables must be set as exogenous. The exogenous variables are chosen so as to approximate a long-run environment. Thus, technical change, direct and indirect tax rates, and industry depreciation rates are exogenous. To capture the overall scarcity of land, we also fix industry land usage. As we are concerned with the reallocation of existing factors rather than growth effects, the national supply of capital is fixed. This assumption means that any excess demands for capital at initial prices (due to structural change) are partly reflected in rental price changes and partly reflected in the reallocation of capital across regions and sectors: capital moves between industries and across regions to maximise its rate of return. The national consumer price index is the numeraire, thus nominal price changes are measured relative to this composite price.

Simulating structural change is also likely to affect government revenue. To neutralise the effect of changes in government revenue in the analysis, we fix the federal budget deficit and endogenise the income tax rate. We also fix the budget deficit for all state governments and endogenise their payroll tax rates. This assumes that for a given level of public expenditure, any additional tax revenue raised due to structural changes will be automatically returned to households through a reduction in their income tax rates, and through higher pre-tax wage rates due to lower payroll tax rates on firms. We also fix supply prices for urban transport industries 
and endogenise the production subsidy/tax on these industries so as to reflect the nature of the pricing reforms to these industries. Before the reforms, many of these industries received significant subsidies to cover their operational deficits. This support was reduced as part of the reform process.

We also assume that real government consumption expenditure is a fixed share of real household consumption expenditure. In turn, household consumption expenditure is a fixed share of household disposable income. Similarly, government investment expenditure is a fixed share of total (private and public) investment expenditure. Private investment expenditure moves in line with changes in each industry's capital stock.

\subsection{The micro dimension}

\subsubsection{Theory}

Regional households in MMRF determine the optimal composition of their consumption bundles via the application of a linear expenditure system (LES) subject to a household budget constraint. The LES divides total consumption of the $i$-th commodity composite into two components: a subsistence (or minimum) part and a luxury (or supernumerary) part. The (percentage-change in) household demand for the $i$-th commodity composite of the $r$-th regional household $\left(q_{i r}^{H}\right)$ is then

$$
q_{i r}^{H}=\left[1-\alpha_{i r}\right] * \operatorname{hou}_{r}+\alpha_{i r} *\left[q l u x_{r}^{H}-p_{i r}^{H}\right]+f_{i r}^{H}
$$

where hou $_{r}$ is the (exogenous) number of households in region $r$, qlux ${ }_{r}^{H}$ is total luxury expenditure of the $r$-th household, $p_{i r}^{H}$ is the consumer price for the $(i, r)$-th good, and $f_{i r}^{H}$ is an exogenous shift term. $\alpha_{i r}$ defines the share of supernumerary expenditure on good $i$ in total expenditure on good $i$. Thus, demand for the $(i, r)$-th good is a positive function of $q l u x_{r}^{H}$ and a negative function of $p_{i r}^{H}$. The sum of these two effects on household demand is controlled by $\alpha_{i r}$, which is defined as $\alpha_{i r}=\alpha^{*} \varepsilon_{i r}$, where $\alpha$ is the 'Frisch parameter'6 and $\varepsilon_{i r}$ is the expenditure elasticity for the $(i, r)$-th good.

\footnotetext{
6 That is, minus the ratio of total expenditure to luxury expenditure.
} 
To determine household demand by commodity at the household level, $q_{i c r}$, we add an equation similar to (10):

$$
q_{i c r}=\left[1-\alpha_{i c r}\right] * h u_{r}+\alpha_{i c r} *\left[q l u x_{r}^{H}-p_{i r}^{H}\right] ;
$$

where $\alpha_{i c r}$ is the share of supernumerary expenditure on good $i$ in total expenditure on good $i$ for the $c$-th household, and is defined as $\alpha_{i c r}=\alpha^{*} \varepsilon_{i c r}$. The values of $\varepsilon_{i c r}$ deviate from $\varepsilon_{i r}$ according to the deviations between the budget shares at the household and regional levels. ${ }^{7}$

To switch from household consumption determined at the aggregate level (equation (10)) to household expenditure determined at the individual household level (equation (11)), we set $f_{i r}^{H}$ as endogenous and add the equation

$$
q_{i r}^{H}=\sum_{c} S_{i c r} * q_{i c r},
$$

where $S_{i c r}$ is the budget share for the $c$-th household. Thus, commodity demand at the aggregate level will be driven by commodity demand at the household level.

To evaluate household welfare, we consider two measures commonly used to compute the benefits that accrue from a price change: compensating variation $(\mathrm{CV})$ and equivalent variation (EV). Both compute the amount of money that would bring the consumer back to their original utility level prior to a price change; $\mathrm{CV}$ values this amount at new prices whereas EV values it using original prices. Both CV and EV apply a 'money-utility' concept rather than utility itself. A modified version of the $\mathrm{CV}$ is based on redefining real income as constant purchasing power. Applying the modified CV concept to measure changes in real income means there is no need to make any specific assumptions about consumer preferences or utility functions.

The computation of CV normally assumes unchanging household income and, therefore, emphasises only the role of each household's consumption patterns in determining the welfare impact of a price change. But in a general equilibrium framework household income is not constant, so we extend the modified CV to account for changing income. For a household, real income can then be defined as nominal factor earnings and transfers received from different sources deflated by the HCPI. Then, the first-order approximation to the percentage change in the $c$-th household's CV, relative to the initial consumption bundle and factor ownership, can be expressed as

\footnotetext{
${ }^{7}$ An alternative would be to assume that $\varepsilon_{i c r}$ is constant across households, e.g., Bourguignon and Savard (2008).
} 


$$
c v_{c}=-\left(i_{c}-p_{c}\right) \text {, }
$$

where $i_{c}$ and $p_{c}$ are the percentage changes in income and the HCPI for $c$-th household. $p_{c}$ is the average percentage change in the prices of the $n$ goods consumed $p_{n}$ weighted by expenditure shares, $p_{c}=\sum_{n} S_{c n} * p_{n}$.

Differences in the sources of income $i_{c}$ for the $c$-th household can be expressed as

$$
i_{c}=\sum_{x} S_{c x} * i_{x}
$$

where $S_{c x}$ is the share of income source $x$ in total household income, and $i_{x}$ is the percentage change in the price of income source $x$. The elements of the set of income sources $x(=33)$ applied here are listed in Table 2, rows 1-4.

\begin{tabular}{|c|c|c|c|}
\hline MMRF & Size & Household accounts & Size \\
\hline $\begin{array}{l}\text { 1. Labour income } \\
\text { sources }\end{array}$ & $m(=8)$ & $\begin{array}{c}\text { Managers, Professionals, Para-Professionals, Tradespersons, Clerks, } \\
\text { Salespersons, Plant/Machine Operators, Labourers }\end{array}$ & $m(=8)$ \\
\hline $\begin{array}{l}\text { 2. Non-labour } \\
\text { income sources }\end{array}$ & $s(=2)$ & $\begin{array}{l}\text { Interest, Investment, Property Rent, Superannuation, Business, Workers' } \\
\text { Compensation, Accident Compensation, Maintenance, Other Regular } \\
\text { Sources, Private Scholarship, Government Scholarship, Overseas Pensions }\end{array}$ & $t(=12)$ \\
\hline $\begin{array}{l}\text { 3. Unemployment } \\
\text { benefits }\end{array}$ & $u(=1)$ & Unemployment Benefits & $u(=1)$ \\
\hline $\begin{array}{l}\text { 4. Other } \\
\text { government } \\
\text { benefits }\end{array}$ & $g(=1)$ & $\begin{array}{l}\text { Sickness Benefits, Family Allowance, Veteran's Pensions, Age Pensions, } \\
\text { Widows' Pensions, Disability Pensions, Supplementary Parent Benefits, } \\
\text { Wife's Pensions, Other Australian Government Benefits, AUSTUDY } \\
\text { Support, Carer's Pensions, Other Overseas Government Benefits }\end{array}$ & $h(=12)$ \\
\hline 5. Income tax & $d(=1)$ & Direct tax & $d(=1)$ \\
\hline Total & 13 & Total & 34 \\
\hline
\end{tabular}

Table 2. Mapping between MMRF income sources and household income sources

The income side of our modified $\mathrm{CV}$ is the amount of money that would encourage households to supply the same amount of factors as prior to any price change. But the general equilibrium effects of industry changes will lead to changes in factor supply and employment, as well as factor returns. To account for such changes, we redefine $i_{c}$ as

$$
i_{c}=\sum_{x} S_{c x}\left(i_{x}+q_{x}\right)
$$

where $q_{x}$ is the percentage change in the employment of income source $x$. Thus, our modified $\mathrm{CV}$ assesses the impact of a policy change on a given household or household group via the computation of the change in real income. 
In computing real household income changes, price and quantity changes are mapped from less detailed MMRF variables to more detailed variables in the household accounts. Commodity prices are mapped as $p_{c n r}=\sum_{k=1}^{54} C M_{k n} * p_{k r}$, where a regional ( $r$ ) subscript has been added and $C M_{k n}$ is a $(0,1)$-integer matrix mapping from MMRF commodities to household expenditure data. The household-specific price index $p_{c r}$ is then equal to $\sum_{n} S_{c n r} * p_{c n r}$ where $S_{c n r}$ is the $(c, r)$-th household's budget share for the $n$-th good.

Table 2 lists the mapping from MMRF income sources to the income sources in the household accounts, including the indices and their sizes; we refer to these indices in the explanation of the mapping that follows. Wages for the $m(=8)$ occupations are mapped as $i_{c m r}=w_{m r}+q_{m r}^{L}$. The $t(=12)$ non-labour income sources are mapped as $i_{c t r}=\sum_{s=1}^{2} S_{s r}\left(p_{s r}^{F}+q_{s r}^{F}\right)$, where $p_{s r}^{F}$ and $q_{s r}^{F}$ are the rental rate and quantity of the $(s, r)$-th non-labour factor (i.e., capital and land), and $S_{s r}$ is the $s$-th factor's share in non-labour income.

For income source $u=$ unemployment benefits, $i_{\text {cur }}=p^{H}+e+n_{r}$, where $p^{H}$ is the national consumer price index, $e$ is the federal government's personal benefits receipts rate, and $n_{r}$ is the number of unemployed in region $r$. For the $h(=12)$ other government benefits, income is mapped as $i_{c h r}=p^{H}+e+s_{r}$, where $s_{r}$ is population in region $r$. Note that $p^{H}$ is the numeraire, and $e$ and $s_{r}$ are assumed to be exogenous. Thus, the $u(=1)+h(=12)$ government benefit payments will only be affected via changes in the number of unemployed. Household income from all income sources is then $i_{c r}=\sum_{x=1}^{33} S_{c x r} * i_{c x r}$, where $S_{c g r}$ is the share of income source $x$ in total income for the $(c, r)$-th household. Real household disposable income, $y_{c r}$, is then $y_{c r}=S I_{c r} * i_{c r}-S T_{c r}\left(i_{c r}+r\right)-p_{c r}$, where $r$ is the income tax rate, and $S I_{c r}$ is the share of total income in disposable income and $S T_{c r}$ is the share of income taxes in disposable income.

\subsubsection{Data}

The household accounts are based on unit-record household data from the 1993-94 Household Expenditure Survey (HES93) (ABS, 1994). The survey contains detailed information on household consumption patterns and income sources of 8,389 sample households in existence around the beginning of the 1990s across the eight Australian states and territories; this gives a 
representation of household income and expenditure around the beginning of the reform period. The HES93 contains income data on the 33 sources listed in Table 2 and expenditure data on more than 700 goods and services.

In reporting distributional effects we group households according to regional income deciles. Given the focus here is the effect of structural change in the urban transport industries, Table 3 presents the national share of household expenditure allocated to urban transport across income deciles. We notice that the share rises slightly as household income increases with the average shares being $0.08 \%$. Table 3 also presents the national distribution of household income across income sources for each decile. Note that government benefits are the dominant source of household income for the first three deciles, whereas labour income is the most important income source for the remaining seven deciles. The data also show a steadily rising direct tax rate as income rises. The data patterns are as expected.

\section{Table 3. Selected expenditure and income shares, national}

\begin{tabular}{|c|c|c|c|c|c|}
\hline \multirow{2}{*}{$\begin{array}{l}\text { Income } \\
\text { decile }\end{array}$} & \multirow{2}{*}{$\begin{array}{c}\text { Share of urban transport } \\
\text { expenditure in total } \\
\text { expenditure }\end{array}$} & \multicolumn{3}{|c|}{$\underline{\text { Household income shares }}$} & \multirow{2}{*}{$\begin{array}{c}\text { Direct tax rate } \\
(\%)\end{array}$} \\
\hline & & $\begin{array}{c}\text { Non-labour } \\
\text { income }\end{array}$ & Labour income & $\begin{array}{c}\text { Government } \\
\text { benefits }\end{array}$ & \\
\hline Lowest & 0.007 & -0.091 & 0.327 & 0.764 & 3.0 \\
\hline Second & 0.007 & 0.099 & 0.417 & 0.485 & 6.0 \\
\hline Third & 0.009 & 0.142 & 0.338 & 0.520 & 6.4 \\
\hline Fourth & 0.008 & 0.109 & 0.501 & 0.390 & 9.3 \\
\hline Fifth & 0.007 & 0.181 & 0.633 & 0.186 & 14.0 \\
\hline Sixth & 0.007 & 0.156 & 0.737 & 0.107 & 16.5 \\
\hline Seventh & 0.008 & 0.158 & 0.771 & 0.071 & 18.5 \\
\hline Eighth & 0.009 & 0.133 & 0.842 & 0.025 & 20.2 \\
\hline Ninth & 0.008 & 0.126 & 0.863 & 0.012 & 22.5 \\
\hline Highest & 0.007 & 0.195 & 0.802 & 0.003 & 29.1 \\
\hline
\end{tabular}

Source: MMRF household accounts. a Non-labour income sources are defined in Table 2. They are based on taxable income; thus, they include losses from business and property income. Such losses dominate non-labour income for the lowest income decile as a whole.

\section{Results}

\subsection{Direct effects: microsimulation}

We initially apply only the changes in relative prices of the urban transport reported in Table 1 on household expenditure. In doing so, we allow households to alter the composition of their expenditure as captured by the LES represented in equation (11). In applying the price changes, we hold total household consumption fixed in nominal terms for each household. Table 4 reports the aggregate effects on real income and its components; to keep the discussion manageable, the changes are aggregated by income deciles. 
Table 4. Effects on household real income and its components (percentage change)

\begin{tabular}{lccc}
\hline \hline Income decile & $\begin{array}{c}(1) \\
\text { Nominal income }\end{array}$ & $\begin{array}{c}(2) \\
\text { Price index }\end{array}$ & $\begin{array}{c}(3) \\
\text { Real income }\end{array}$ \\
\hline Lowest & 0.00 & 0.22 & -0.22 \\
Second & 0.00 & 0.21 & -0.22 \\
Third & 0.00 & 0.29 & -0.29 \\
Fourth & 0.00 & 0.21 & -0.21 \\
Fifth & 0.00 & 0.18 & -0.18 \\
Sixth & 0.00 & 0.19 & -0.19 \\
Seventh & 0.00 & 0.23 & -0.23 \\
Eighth & 0.00 & 0.38 & -0.24 \\
Ninth & 0.00 & 0.23 & -0.23 \\
Highest & 0.00 & 0.19 & -0.19 \\
\hline \hline
\end{tabular}

Source: Authors' simulation.

All income deciles experience a welfare loss and this is completely due to the rise in the price of the consumption basket as nominal income is assumed to remain unchanged by the price changes. The rise in the price of consumption is purely due to higher prices for urban transport as the price of all other goods are held fixed for this simulation. The welfare loss is around $0.2 \%$ for all households except the third $(0.29 \%)$ and eighth deciles $(0.38 \%)$. This reflects the greater importance of urban transport in the consumption basket for these deciles compared to other deciles as shown in Table 3. Detailed results by region are presented in Table 5. We see that households in all regions are worse off but by varying proportions: this reflects the general rise in the price of urban transport industries in all regions reported in Table 1 and the regional variation in those price rises. As a reflection of the regional variation in price rises, the largest welfare losses are experienced by households in QLD (-0.54\%) and WA (-0.26\%). The income changes are estimated to have little effect on income distribution as indicated by the national and regional Gini coefficients. 
Table 5. Effects on household real income and inequality (percentage change)

\begin{tabular}{lccccccccc}
\hline \hline Income decile & NSW & VIC & QLD & SA & WA & TAS & NT & ACT & Aust \\
\hline Lowest & -0.12 & -0.09 & -0.62 & -0.10 & -0.44 & -0.08 & -0.03 & -0.16 & -0.22 \\
Second & -0.13 & -0.10 & -0.55 & -0.19 & -0.35 & -0.05 & -0.04 & -0.15 & -0.22 \\
Third & -0.16 & -0.12 & -0.90 & -0.24 & -0.27 & -0.05 & -0.02 & -0.14 & -0.29 \\
Fourth & -0.15 & -0.13 & -0.42 & -0.26 & -0.25 & -0.06 & -0.03 & -0.21 & -0.21 \\
Fifth & -0.16 & -0.13 & -0.38 & -0.13 & -0.13 & -0.10 & -0.02 & -0.05 & -0.18 \\
Sixth & -0.15 & -0.11 & -0.49 & -0.15 & -0.12 & -0.08 & -0.03 & -0.15 & -0.19 \\
Seventh & -0.16 & -0.11 & -0.58 & -0.13 & -0.34 & -0.07 & -0.02 & -0.11 & -0.23 \\
Eighth & -0.18 & -0.12 & -0.58 & -0.21 & -0.19 & -0.09 & -0.03 & -0.10 & -0.24 \\
Ninth & -0.17 & -0.14 & -0.57 & -0.13 & -0.31 & -0.04 & -0.03 & -0.06 & -0.23 \\
Highest & -0.14 & -0.11 & -0.43 & -0.24 & -0.22 & -0.11 & -0.09 & -0.05 & -0.19 \\
All deciles & -0.15 & -0.12 & -0.54 & -0.17 & -0.26 & -0.07 & -0.04 & -0.11 & -0.22 \\
Gini coefficient & 0.00 & 0.00 & 0.03 & 0.00 & 0.01 & -0.01 & -0.01 & 0.02 & 0.00 \\
\hline \hline
\end{tabular}

Source: Authors' simulation.

\subsection{Direct and indirect effects: top-down general equilibrium}

Next we apply the changes in relative prices and unit-output employment for urban transport to the model described in Section 3.2; in doing so, we do not allow any micro feedback effects to the macro level: this assumption is relaxed in the next section. A CGE model captures both the direct and indirect effects of a given shock to the economy. The direct effects on households' budgets have already been explored in the previous section. Here we explore the direct effects of structural change in the urban transport industries. The major determinant of the direct effects of structural change in the urban transport industries is their combined importance in the economy as a whole. Our model data indicates that value-added for these industries made up around $0.3 \%$ of national value-added. This varies from $0.1 \%$ in the ACT to $0.4 \%$ in NSW, VIC and QLD. Thus, a priori, we would expect the direct effects from structural change to vary across regions but to be quite small.

The macroeconomic effects are reported in Table 6. Most regions (NSW, VIC, SA, TAS and NT) experience small increases in output and the rest experience small decreases; national real GDP is approximately constant. The changes in output are a function of factor usage and productivity. Productivity rises in all regions except TAS, NT and ACT. In all regions where productivity rises, factor usage falls and the size of the fall relative to the productivity improvement determines whether regional GDP rises or falls. Thus, GDP rises in NSW, VIC and SA because in these regions the productivity improvement is large relative to the fall in factor usage; conversely, in QLD and WA the productivity improvement is small relative to the fall in factor usage and so GDP falls. Thus, QLD and WA experience the largest falls in GDP (-0.32\% and $-0.08 \%$ ); related to this, both regions experience a relatively large rise in the prices of 
consumer goods $(0.29 \%$ and $0.08 \%)$. Below we explain in more detail the microeconomic origins of the macroeconomic effects.

Table 6. Macroeconomic effects of changes in urban transport: 1989/90-1999/00 (percentage change)

\begin{tabular}{lccccccccc}
\hline \hline Variable & NSW & VIC & QLD & SA & WA & TAS & NT & ACT & Aust \\
\hline Employment & -0.15 & -0.16 & -0.35 & -0.15 & -0.20 & 0.02 & 0.02 & 0.02 & -0.18 \\
Capital & 0.08 & 0.11 & -0.33 & 0.01 & -0.07 & 0.11 & 0.10 & 0.13 & 0.00 \\
Productivity & 0.11 & 0.15 & 0.01 & 0.09 & 0.06 & -0.01 & 0.00 & -0.05 & 0.09 \\
Real wage rate & -0.07 & -0.07 & -0.25 & -0.08 & -0.11 & 0.00 & 0.03 & 0.02 & -0.10 \\
Terms of trade & & & & & & & & & -0.02 \\
Real exchange rate & & & & & & & & & 0.06 \\
CPI & -0.07 & -0.09 & 0.29 & -0.03 & 0.08 & -0.09 & -0.09 & -0.05 & 0.00 \\
Real GDP & 0.08 & 0.12 & -0.32 & 0.02 & -0.08 & 0.03 & 0.04 & -0.01 & 0.00 \\
\hline \hline
\end{tabular}

Source: MMRF simulation.

The effects on the urban transport industries are reported in Table 7. The estimated changes in unit-output employment will determine the changes in labour productivity. Table 7 also reports the average productivity change for each industry; these average changes do not impact on the supply prices for each industry as we have assumed that the supply prices will remain constant. The difference between the average change in productivity and the supply price constitutes a reduction (increase) in the production subsidy (tax) for each industry. Average productivity is projected to improve in most regions but the largest improvements are in NSW and VIC; as expected, the largest improvements are for rail transport. Table 7 also reports the changes in the tax rate paid by households consuming urban transport, which represent the divergence between the (constant) supply price and the higher relative prices listed in Table 1. The largest tax rate increases are in QLD and WA, which explains the relatively large CPI increases reported in Table 6. Thus, households consume less in QLD and WA and this has a stronger contractionary effect on economic activity in these regions than in other regions. However, the extra tax revenue raised in these regions is returned equiproportionately to all industries in these regions via a lower payroll tax rate; this has an expansionary effect on economic activity. Despite this, the redistribution from households to firms is contractionary overall in QLD and WA as it is not accompanied by productivity improvements as large as those in NSW, VIC and SA. 
Table 7. Urban transport industry effects due to changes in unit-output employment and relative output prices: 1989/90-1999/00 (percentage change)

\begin{tabular}{|c|c|c|c|c|c|c|c|c|}
\hline Variable & NSW & VIC & QLD & SA & WA & TAS & NT & ACT \\
\hline & \multicolumn{8}{|c|}{ Road transport } \\
\hline Labour productivity & -1.6 & -4.4 & -0.6 & -3.0 & -2.5 & 0.3 & 0.0 & 4.5 \\
\hline Average productivity & -0.7 & -2.0 & -0.2 & -1.3 & -1.1 & 0.2 & 0.0 & 1.9 \\
\hline \multirow[t]{2}{*}{ Household consumption tax rate $\mathbf{b}^{\mathbf{b}}$} & 12.7 & 14.6 & 68.8 & 18.7 & 40.8 & 19.2 & 22.2 & 39.5 \\
\hline & \multicolumn{8}{|c|}{ Rail transport } \\
\hline Labour productivity ${ }^{\mathbf{a}}$ & -17.1 & -21.1 & -0.1 & -9.8 & -9.1 & 0.0 & 0.0 & 0.0 \\
\hline Average productivity & -7.1 & -8.5 & -0.1 & -3.8 & -1.0 & 0.0 & 0.0 & 0.0 \\
\hline \multirow[t]{2}{*}{ Household consumption tax rate ${ }^{\mathbf{b}}$} & 9.6 & 4.5 & 4.7 & 9.0 & 19.5 & 0.0 & 0.0 & 0.0 \\
\hline & \multicolumn{8}{|c|}{ Water transport } \\
\hline Labour productivitya & 1.1 & 0.0 & -2.7 & 0.0 & 0.3 & 0.0 & 0.0 & 0.0 \\
\hline Average productivity & 0.2 & 0.0 & -0.4 & 0.0 & 0.0 & 0.0 & 0.0 & 0.0 \\
\hline Household consumption tax rate $\mathbf{b}^{\mathbf{b}}$ & 13.5 & 0.0 & 74.2 & 0.0 & 43.9 & 0.0 & 0.0 & 0.0 \\
\hline
\end{tabular}

Source: MMRF simulation.

$\mathbf{a}$ This is the input requirement per unit of output; thus, a negative sign signifies an improvement. $\mathbf{b}$ This is the percentage-point change in the tax rate.

The national changes in relative occupational incomes (Table 8) indicate those occupations most favoured by the industry changes. Most occupations experience either small increases or no change in relative incomes; the exception is Plant and machine operators, drivers who experience a large fall in relative incomes. This is because about one-fifth of all wage payments in the urban transport industries are made to this occupational group. Thus, when significant labour shedding occurs in these industries, particularly rail transport, Plant and machine operators, drivers are most affected, and consequently the wage rate for this occupational group must fall for these workers to be reemployed in other industries. Occupations that are least used in the urban transport industries experience the largest increases in relative incomes, e.g., Professionals. 
Table 8. Microeconomic effects of changes in the urban transport industries: 1989/901999/00 (percentage change)

\begin{tabular}{lccccccccc}
\hline \hline Variable & NSW & VIC & QLD & SA & WA & TAS & NT & ACT & Aust \\
\hline Labour income & -0.27 & -0.32 & -0.25 & -0.24 & -0.24 & -0.04 & -0.04 & 0.03 & -0.26 \\
Managers \& administrators & -0.12 & -0.19 & -0.21 & -0.16 & -0.19 & -0.04 & -0.04 & 0.01 & -0.16 \\
Professionals & -0.09 & -0.06 & -0.23 & -0.10 & -0.13 & -0.02 & -0.03 & -0.09 & -0.10 \\
Para-professionals & -0.31 & -0.25 & -0.25 & -0.17 & -0.17 & 0.01 & 0.00 & -0.07 & -0.24 \\
Tradespersons & -0.22 & -0.21 & -0.24 & -0.17 & -0.16 & -0.08 & -0.05 & 0.02 & -0.20 \\
Clerks & -0.18 & -0.19 & -0.23 & -0.18 & -0.19 & -0.04 & -0.05 & -0.05 & -0.18 \\
Salespersons \& personal service workers & -0.31 & -0.32 & -0.22 & -0.24 & -0.23 & -0.03 & -0.04 & 0.03 & -0.27 \\
Plant \& machine operators; drivers & -1.16 & -1.65 & -0.45 & -1.09 & -0.85 & -0.07 & -0.11 & 1.13 & -1.06 \\
Labourers \& related workers & -0.17 & -0.16 & -0.23 & -0.15 & -0.16 & -0.06 & -0.05 & -0.02 & -0.17 \\
Non-labour income & -0.19 & -0.16 & -0.53 & -0.24 & -0.30 & -0.12 & -0.12 & -0.07 & -0.25 \\
Unemployment benefits & 1.21 & 1.14 & 2.92 & 1.16 & 1.98 & -0.04 & -0.06 & -0.11 & 1.48 \\
Direct tax rate & & & & & & & & & -0.14 \\
\hline \hline
\end{tabular}

Source: Authors' simulation.

The national pattern of relative changes in occupational incomes is generally repeated at the regional level but with different absolute changes across regions. In general, the relative movements in labour income across regions reflect the relative productivity changes across regions; greater relative productivity improvements lead to greater reductions in relative labour incomes and vice versa. This effect is especially notable when comparing the change in relative incomes for Plant and machine operators, drivers across regions, and it is quite strong in NSW, VIC and SA. This paradoxical result reflects the lack of downstream beneficiaries from the improvement in labour productivity in the urban transport industries, as urban transport is mainly consumed by households rather than other industries. So although productivity improves in the urban transport industries, this does not lower costs for other industries that might otherwise reemploy redundant workers. Thus we observe a negative co-movement of productivity and wage incomes in the simulations. Non-labour income also decreases nationally reflecting increased demand for capital and land. The relative changes in non-labour income across regions reflect the pattern of movements of capital across regions. Unemployment benefits rise in all regions that experience lower employment (NSW, VIC, QLD, SA and WA) and fall in regions that experience higher employment (all other regions). We also observe a fall in the direct tax rate $(-0.14 \%)$ due to the improvement in the allocation of resources, and therefore the tax base, as the subsidies to urban transport industries are removed or reduced.

The changes in individual household real income are presented by income deciles in Table 9. At the national level most income deciles lose; higher income deciles tend to lose more than lower income deciles. In aggregate, the loss is marginal $(-0.2 \%)$. The income changes are 
slightly progressive as shown by the small fall in the national Gini coefficient $(-0.03 \%)$. The national pattern of progressive income effects is replicated in all regions except those regions where little structural change occurred, i.e., TAS, NT and ACT. A decomposition of the change in real household income into nominal income and price changes (Table 10) indicates that nationally the differences in real household income changes across deciles are a reflection of both price and income effects (columns 1 and 2) but their relative importance varies by income decile. For the first four deciles, price effects are at least as important as income effects; for higher income deciles, income effects dominate the real income effects. Further, the decomposition shows that, except for the first decile, the price and income effects are reinforcing as both move such that they reduce real income.

Table 9. Effects on household real income and inequality (percentage change)

\begin{tabular}{lccccccccc}
\hline \hline Income decile & NSW & VIC & QLD & SA & WA & TAS & NT & ACT & Aust \\
\hline Lowest & 0.09 & 0.17 & -0.33 & 0.09 & -0.29 & 0.03 & 0.08 & -0.02 & 0.01 \\
Second & 0.01 & 0.02 & -0.44 & 0.03 & -0.19 & 0.06 & 0.07 & 0.02 & -0.09 \\
Third & -0.01 & 0.12 & -0.71 & 0.00 & -0.09 & 0.06 & 0.07 & -0.01 & -0.10 \\
Fourth & -0.08 & -0.09 & -0.33 & -0.09 & -0.15 & 0.06 & 0.06 & -0.04 & -0.13 \\
Fifth & -0.13 & -0.10 & -0.48 & -0.10 & -0.04 & 0.02 & 0.07 & 0.07 & -0.17 \\
Sixth & -0.17 & -0.13 & -0.58 & -0.20 & -0.16 & 0.03 & 0.08 & 0.02 & -0.22 \\
Seventh & -0.18 & -0.11 & -0.66 & -0.14 & -0.33 & 0.05 & 0.09 & 0.04 & -0.24 \\
Eighth & -0.21 & -0.21 & -0.70 & -0.23 & -0.23 & 0.03 & 0.09 & 0.02 & -0.29 \\
Ninth & -0.19 & -0.16 & -0.72 & -0.19 & -0.36 & 0.08 & 0.09 & 0.08 & -0.27 \\
Highest & -0.09 & -0.09 & -0.59 & -0.25 & -0.23 & 0.03 & 0.05 & 0.10 & -0.19 \\
All deciles & -0.12 & -0.09 & -0.60 & -0.15 & -0.24 & 0.05 & 0.08 & 0.03 & -0.20 \\
Gini coefficient & -0.03 & -0.04 & -0.04 & -0.06 & -0.03 & 0.00 & 0.00 & 0.02 & -0.03 \\
\hline \hline
\end{tabular}

Source: Authors' simulation.

The decomposition of the income effects (Table 10, columns 3-6) shows that, nationally, all deciles experience lower labour and capital income reflecting the reductions in primary factor income explained earlier. Government benefit payments also rise for most deciles due to the increase in the unemployed. The reductions in labour income are largest for higher income deciles as the occupation that is most negatively affected by the structural change, Plant and machine operators, drivers, is more heavily represented in higher deciles than lower deciles. Further, lower income deciles benefit more from the rise in unemployment benefits than higher income deciles. Although higher income deciles are the main beneficiaries of the fall in the direct tax rate, this is not enough to offset the progressivity of the other income effects. 
Table 10. Decomposition of national household income effects

\begin{tabular}{|c|c|c|c|c|c|c|}
\hline \multirow[t]{3}{*}{ Income decile } & \multicolumn{2}{|c|}{$\frac{\text { Components of real income }}{\text { (percentage change) }}$} & \multicolumn{4}{|c|}{$\frac{\text { Components of nominal income }}{\text { (percentage-point change) }}$} \\
\hline & (1) & (2) & (3) & (4) & (5) & (6) \\
\hline & $\begin{array}{l}\text { Nominal } \\
\text { income }\end{array}$ & $\begin{array}{l}\text { Price } \\
\text { index }\end{array}$ & $\begin{array}{l}\text { Labour } \\
\text { income }\end{array}$ & $\begin{array}{l}\text { Capital } \\
\text { income }\end{array}$ & $\begin{array}{l}\text { Government } \\
\text { benefits }\end{array}$ & $\begin{array}{l}\text { Direct } \\
\text { taxes }\end{array}$ \\
\hline Lowest & 0.07 & 0.06 & -0.07 & -0.05 & 0.19 & 0.00 \\
\hline Second & -0.02 & 0.07 & -0.13 & -0.02 & 0.12 & 0.01 \\
\hline Third & 0.03 & 0.13 & -0.08 & -0.04 & 0.13 & 0.01 \\
\hline Fourth & -0.08 & 0.05 & -0.14 & -0.03 & 0.07 & 0.02 \\
\hline Fifth & -0.14 & 0.02 & -0.18 & -0.05 & 0.03 & 0.05 \\
\hline Sixth & -0.18 & 0.03 & -0.24 & -0.05 & 0.03 & 0.07 \\
\hline Seventh & -0.17 & 0.07 & -0.23 & -0.05 & 0.03 & 0.08 \\
\hline Eighth & -0.21 & 0.08 & -0.27 & -0.04 & 0.01 & 0.10 \\
\hline Ninth & -0.20 & 0.07 & -0.27 & -0.04 & 0.00 & 0.11 \\
\hline Highest & -0.16 & 0.03 & -0.23 & -0.08 & 0.00 & 0.15 \\
\hline
\end{tabular}

Source: Authors' simulation.

a Column (1) minus column (2) equals the percentage change in real national household income. $\mathbf{b}$ The summation of columns (3)-(6) equals column (1).

\subsection{Direct and indirect effects: top-down/bottom-up general equilibrium}

We now apply the changes in relative prices and unit-output employment for the urban transport industries to our model but here we allow micro feedback to the macro level via (i) labour supply, and (ii) household commodity demand. The changes in individual household real income are presented in Table 11. At the national level, the top-down/bottom-up results are identical to the top-down results presented above; aggregate real income is $0.2 \%$ lower and the national Gini coefficient declines by $0.03 \%$. The aggregate effects on real income and distribution accurately reflect the similarity of the top-down/bottom-up effects to the top-down effects at the decile and regional level.

The similarity of the top-down/bottom-up results to the top-down results indicate that whether labour supply and commodity demand is determined at the macro or micro level is not important to the effects on income and its distribution in the present work. This result is supported by the work of Bourguignon and Savard (2008): comparing the effects of trade liberalisation in the Phillipines on income distribution, they found their results were invariant to the inclusion of micro feedback effects. Thus, our results confirm the adequacy of the purely topdown approach in macro-micro distributional analysis. But it should also be noted that it is not possible to know ex ante whether the distributional effects of a particular policy or other change is insensitive to micro feedback effects; the insensitivity or otherwise must be confirmed empirically. As such, we feel that both our results and those of Bourguignon and Savard (2008) do not negate the case for incorporating micro feedback effects in macro-micro distributional 
analysis, and the criticisms directed at the macro-micro approach due to the absence of micro feedback effects by Bourguignon and Spadaro (2006) and Hertel and Reimer (2005) remain valid.

Table 11. Effects on household real income and inequality (percentage change)

\begin{tabular}{lccccccccc}
\hline \hline Income decile & NSW & VIC & QLD & SA & WA & TAS & NT & ACT & Aust \\
\hline Lowest & 0.08 & 0.16 & -0.35 & 0.08 & -0.29 & 0.02 & 0.08 & -0.03 & -0.01 \\
Second & 0.00 & 0.01 & -0.44 & 0.02 & -0.20 & 0.06 & 0.07 & 0.01 & -0.10 \\
Third & -0.01 & 0.11 & -0.72 & -0.01 & -0.10 & 0.05 & 0.07 & -0.01 & -0.11 \\
Fourth & -0.08 & -0.09 & -0.34 & -0.09 & -0.15 & 0.06 & 0.06 & -0.04 & -0.13 \\
Fifth & -0.13 & -0.10 & -0.48 & -0.10 & -0.04 & 0.02 & 0.08 & 0.08 & -0.16 \\
Sixth & -0.17 & -0.13 & -0.58 & -0.20 & -0.16 & 0.03 & 0.08 & 0.02 & -0.22 \\
Seventh & -0.17 & -0.10 & -0.66 & -0.14 & -0.33 & 0.05 & 0.09 & 0.04 & -0.24 \\
Eighth & -0.21 & -0.20 & -0.70 & -0.23 & -0.23 & 0.03 & 0.09 & 0.02 & -0.29 \\
Ninth & -0.19 & -0.15 & -0.71 & -0.18 & -0.35 & 0.09 & 0.10 & 0.08 & -0.27 \\
Highest & -0.09 & -0.09 & -0.58 & -0.24 & -0.22 & 0.03 & 0.05 & 0.10 & -0.18 \\
All deciles & -0.12 & -0.09 & -0.60 & -0.15 & -0.23 & 0.05 & 0.08 & 0.03 & -0.20 \\
Gini coefficient & -0.02 & -0.04 & -0.04 & -0.05 & -0.03 & 0.00 & 0.00 & 0.02 & -0.03 \\
\hline \hline
\end{tabular}

Source: Authors' simulation.

\section{Discussion and concluding remarks}

We analyse the distributional impacts of structural changes in Australian urban transport industries during the 1990s, as captured by unit-output employment and relative prices. The structural changes in these industries were mainly driven by the implementation of microeconomic reform policies. The rate and nature of the reforms varied across Australian regions; thus, there was also significant variation in the structural changes across regions. To assess the distributional impact of these changes we initially apply a top-down macro-micro approach: we incorporate detailed household income and expenditure accounts within a multiregion computable general equilibrium model of Australian regions. Our study is motivated by the desire to assess the distributional impacts of microeconomic reform on urban transport industries, especially due to the seemingly strong direct links (through direct purchases by households) and weak indirect links (due to the absence of inter-industry usage) between urban transport industries and income distribution.

Our results indicate that the changes experienced by urban transport industries over the 1990s had small but noticeable impacts on household real income and income distribution. Overall, household real income fell by $0.2 \%$. This hides the uneven distribution of the effects across regions; households in NSW (-0.12\%), QLD (-0.60\%) and WA $(-0.24 \%)$ lose the most whereas households in TAS $(0.05 \%)$, NT $(0.08 \%)$ and ACT gain $(0.03 \%)$. For most regions, 
income inequality, as measured by the Gini coefficient, falls; nationally, inequality is estimated to have decreased slightly with a $0.03 \%$ fall in the coefficient. We test the sensitivity of our results by comparing it to a traditional microsimulation approach and find that, compared to the topdown macro-micro approach, it gives accurate results at the aggregate level but underestimates the variation in effects across deciles and regions.

Structural change in the urban transport industries is estimated to have improved labour productivity, particularly so for rail transport compared to road and water transport. The improvements in labour productivity allow government support for operational deficits in urban transport to be removed or reduced: this was a feature of the reforms to these industries. At the same, governments increased the prices charged for urban transport, in some cases significantly so. Thus households experience lower real income from cost-recovery pricing; this finding is similar to that of Boccanfuso et al. $(2009 \mathrm{a}, \mathrm{b})$ in their analysis of electricity reform in Mali and Senegal. In contrast, the general equilibrium effects of the reforms were to lower the prices of other goods and services due to the contractionary effect of the increases in urban transport prices and reductions in urban transport employment. Returning the extra taxation revenue to households via lower income and payroll tax rates partly ameliorates these effects. Nevertheless, the absence of downstream beneficiaries from the urban transport reforms means there is an absence of strong positive indirect effects from the reforms. The absence of strong positive indirect effects from the reforms means that when labour shedding occurs in the urban transport industries due to improved labour productivity, displaced workers must accept larger cuts in wage rates to be reemployed in other industries than would otherwise be the case. Downward rigidity in wage rates means that many workers are not reemployed and unemployment increases strongly in most regions; this mainly affects workers in lower income deciles but they are partly compensated by increased government benefits. The pattern of lower wage rates adversely affects higher income deciles more than lower income deciles, leading to progressive nominal income effects.

The absence of strong positive indirect effects from the urban transport reforms contrasts with the work of Boccanfuso et al. (2009a, b). Taken together, our work and that of Boccanfuso et al. (2009a, b) suggests that where cost-recovery pricing is implemented in an industry with strong inter-industry links (e.g. electricity) indirect effects are likely to be large; where it is implemented in an industry with weak inter-industry links (e.g., urban transport) the indirect effects are likely to be small. 
We also test the sensitivity of our results to the determination of labour supply and commodity demand at the macro and micro (household) level. Our results are invariant to the use of a top-down or top-down/bottom-up framework, supporting the findings of Bourguignon and Savard (2008). Thus, our results provide further evidence of the adequacy of the top-down approach in macro-micro distributional analysis despite the criticisms directed at the macro-micro approach due to the absence of micro feedback effects (Bourguignon and Spadaro, 2006; Hertel and Reimer, 2005). But it also not possible to know ex ante whether the distributional effects of a particular policy or other change is insensitive to micro feedback effects: the insensitivity or otherwise must be confirmed empirically. This is one contribution of this study.

Although we find that the absence of micro feedback effects to be unimportant in this study, there are few studies that test the importance of such effects. Of the handful of studies analysing the distributional effect of reforming infrastructure industries using a macro-micro approach (i.e., Boccanfuso et al., 2009a, b; PC, 1996; Verikios and Zhang, 2008), none include a micro-feedback effect at the household level. Thus, our work represents an advance on studies that analyse the distributional effects of reforming infrastructure industries using a macro-micro approach. Another contribution of our analysis is that we have estimated the distributional effects of a policy change that was strongly resisted for nearly a century by Australian governments, their constituents and many economists. We have shown that previously stateowned monopoly industries can experience significant structural changes while generating marginal effects on household income and its distribution: this is an important research finding. Nevertheless, we find that workers displaced from the reforming industries bear the burden of the reform process via lower real wages and higher unemployment. Our analysis suggests that policy makers in Australia and other high-income nations should give serious consideration to reforming industries that run operational deficits: such reforms may improve operational efficiency and reduce deficits with little change in income inequality. 


\section{References}

Adams, P.D., Horridge, J.M. and Parmenter, B.R. (2000), MMRF-GREEN: A Dynamic, Multi-Sectoral, Multi-Regional Model of Australia, Centre of Policy Studies/IMPACT Centre, Working Paper OP-94, Monash University, October.

Andersen, L.E. and Faris, R. (2002), Natural Gas and Income Distribution in Bolivia, Andean Competitiveness Project Working Paper, Instituto de Investigaciones Socio-Económicas, Catholic University of Bolivia, La Paz, and Center for International Development, Harvard University, February.

ABS (Australian Bureau of Statistics) (1994), 1993-94 Household Expenditure Survey, Australia: Unit Record File, Cat. No. 6535.0, ABS, Canberra.

Benitez, D., Chisari, O. and Estache, A. (2003), 'Can the gains from Argentina's utilities reform offset credit shocks?', in Ugaz, C. and Price, C.W. (eds), Utility Privatization and Regulation: A Fair Deal for Consumers?, Edward Elgar, Northampton, MA, pp. 175-202.

Boccanfuso, D., Estache, A. and Savard, L. (2009a), 'A macro-micro analysis of the effects of electricity reform in Senegal on poverty and distribution', Journal of Development Studies, vol. 45, no. 3, pp. 351-68.

(2009b), 'Electricity reforms in Mali: a macro-micro analysis of the effects on poverty and distribution', South African Journal of Economics, vol. 77, no. 1, pp. 127-47.

Bourguignon, F. and Savard, L. (2008) "Distributional effects of trade reform: an integrated macro-micro model applied to the Philippines" in Bourguignon, F., Pereira Da Silva, L.A. and Bussolo, M. (eds.), The Impact of Macroeconomic Policies on Poverty and Income Distribution: Macro-Micro Evaluation Techniques and Tools, Palgrave-Macmillan Publishers Limited, Houndmills, Angleterre, pp. 177-211.

Bourguignon, F. and Spadaro, A. (2006), 'Microsimulation as a tool for evaluating redistribution policies', Journal of Economic Inequality, vol. 4, no. 1, pp. 77-106.

Chen, S. and Ravallion, M. (2004), 'Welfare impacts of China's accession to the World Trade Organization, World Bank Economic Review, vol. 18, no. 1, pp. 29-57.

Cockburn, J., Corong, E. and Cororaton, C.B. (2008), 'Poverty effects of the Philippines' tariff reduction program: insights from a computable general equilibrium framework', Asian Economic Journal, vol. 22, issue 3, pp. 289-319.

Cogneau, D. and Robilliard, A-S. (2000), Growth, Distribution and Poverty in Madagascar: Learning From a Microsimulation Model in a General Equilibrium Framework, TMD Discussion Paper 61, International Food Policy Research Institute, Washington DC.

Commonwealth of Australia (1993), National Competition Policy, Report by the Independent Committee of Inquiry (Hilmer Report), Commonwealth Government Printer, Canberra.

Davies, J. (2004), 'Microsimulation, CGE and macro modelling for transition and developing economics', Paper prepared for the United Nations University / World Institute for Development Economics Research (UNU/WIDER), Helsinki.

Dixon, P.B. and Rimmer, M.T. (2002), Dynamic General Equilibrium Modelling for Forecasting and Policy: A Practical Guide and Documentation of MONASH, Contributions to Economic Analysis 256, North-Holland Publishing, Amsterdam.

and Wittwer, G. (2011), 'Saving the Southern Murray-Darling Basin: the economic effects of a buyback of irrigation water', Economic Record, vol. 87, no. 276, pp. 153-68.

Harrison, W.J. and Pearson, K.R. (1996), 'Computing solutions for large general equilibrium models using GEMPACK', Computational Economics, vol. 9, no. 2, pp. 83-127.

Hertel, T.W. and Reimer, J.J. (2005), 'Predicting poverty impacts of trade reform', Journal of International Trade and Economic Development, vo. 14, no. 4, pp. 377-405. 
Horridge, M., Madden, J. and Wittwer, G. (2005), 'The impact of the 2002-2003 drought on Australia', Journal of Policy Modeling, vol. 27, no. 3, pp. 285-308.

IC (Industry Commission) (1994), Urban Transport (2 Volumes), Australian Government Publishing Service, Melbourne.

Johansen, L. (1960), A Multisectoral Study of Economic Growth, North-Holland, Amsterdam.

Kalb, G. (1997), An Australian Model for Labour Supply and Welfare Participation in Two-Adult Households, $\mathrm{PhD}$ thesis, Monash University, October.

Kennedy, S and Borland, J. (2000), 'A wage curve for Australia?', Oxford Economic Papers, vol. 52, pp. 774-803.

Löfgren, H., Doukkali, R., Serghini, H. and Robinson, S. (1997), Rural Development in Morocco: Alternative Scenarios to the Year 2000, TMD Discussion Paper 17, International Food Policy Research Institute, Washington DC.

Metro Tasmania (2001), Annual Report 2000/2001, Metro Tasmania, Hobart.

Naqvi, F. and Peter, M.W. (1996), 'A multiregional, multisectoral model of the Australian economy with an illustrative application', Australian Economic Papers, vol. 35, issue 66, pp. 94-113.

Orcutt, G.H. (1967) 'Microeconomic analysis for prediction of national accounts', in Wold, H., Orcutt, G.H., Robinson, E.A., Suits, D. and de Wolff, P. (eds.), Forecasting on a Scientific Basis: Proceedings of an International Summer Institute, Centro de Economia e Financas, Lisbon, pp. 67127.

PC (Productivity Commission) (1996), Reform and the Distribution of Income: An Economy-wide Approach, Staff Information Paper.

(2002), Trends in Australian Infrastructure Prices 1990-91 to 2000-01, Performance Monitoring, AusInfo, Canberra.

(2006), Road and Rail Freight Infrastructure Pricing, Report no. 41, Commonwealth of Australia, Canberra, December.

Quiggin, J. (1997), 'Estimating the benefits of Hilmer and related reforms', The Australian Economic Review, vol. 30, no. 3, pp. 256-72.

Savard, L. (2010), 'Scaling up infrastructure spending in the Philippines: a CGE top-down bottom up microsimulation approach', International Journal of Microsimulation, vol. 3, no. 1, pp. 43-59.

SCNPMGTE (Steering Committee on National Performance Monitoring of Government Trading Enterprises) (1995), Government Trading Enterprises Performance Indicators: 1989-90 to 1993-94, Volume 2, SCNPMGTE.

— (1996), Government Trading Enterprises Performance Indicators: 1990-91 to 1994-95, Volume 2, SCNPMGTE.

(1998), Government Trading Enterprises Performance Indicators: 1992-93 to 1996-97, SCNPMGTE.

SCRGSP (Steering Committee for the Review of Government Service Provision) (1998), Report on Government Services 1998, Productivity Commission, Canberra.

Verikios, G. and Zhang, X-G. (2005), Modelling Changes in Infrastructure Industries and Their Effects on Income Distribution, Research Memorandum MM-44, Productivity Commission, September.

(2008), Distributional Effects of Changes in Australian Infrastructure Industries During the 1990s, Staff Working Paper, Productivity Commission, January.

Williams, R., Greig, D. and Wallis, I. (2005), Results of Railway Privatization in Australia and New Zealand, Transport Paper No. TP-7, The World Bank Group, Washington D.C., September.

Wittwer, G., McKirdy, S. and Wilson, R. (2005), 'Regional economic impacts of a plant disease incursion using a general equilibrium approach', Australian Journal of Agricultural and Resource Economics, vol. 49 , no. 1 , pp. $75-89$. 